\title{
Development of Nakdong River Estuary Ecosystem Model Using AQUATOX Model
}

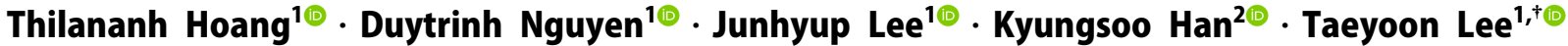 \\ 'Department of Environmental Engineering, Pukyong National University \\ ${ }^{2}$ Department of Spatial Information Engineering, Pukyong National University
}

(Received December 10, 2020; Revised December 28, 2020; Accepted January 4, 2021)

Objectives: In this study, a model representing the ecosystem of the Nakdong River Estuary was constructed using the AQUATOX model, and the ecosystem model was calibrated using the measured data, and the Nakdong River Estuary ecosystem was predicted by using the calibrated model.

Methods: After constructing the Nakdong River Estuary Ecosystem Model using the AQUATOX model provided by the US EPA, the model was calibrated using the measurement data for the Nakdong River Estuary. The model calibration was performed on the measured chlorophyll-a, and the DO, total nitrogen, total phosphorus, crab, shrimp, and fish measurement data were compared with the values derived from the calibrated model and verified. Using the final verified model, we predicted the ecosystem change that occurs when the pesticide component $(0.4$ $\mathrm{ug} / \mathrm{L}$ ) is temporarily and continuously introduced into the Nakdong estuary area from the upper stream of the Nakdong River.

Results and Discussion: The calibration results of the ecosystem model for the measured chlorophyll-a were RB (0.029), F (1.35), RSME (0.489), and MAE (0.105). The phytoplankton in the estuary consisted of cryptomonas, greens, diatoms, blue-green algae, and the cryptomonas grew in the estuary as a habitat, but the rest of the phytoplankton were introduced into the estuary through the effluent of Nakdong river. In the case of zooplankton, copepods are the dominant species, but all of them are found to be released into the ocean when the effluent from Nakdong river is introduced. In the case of crustaceans, crab and shrimp were the dominant species, and the values of these models were similar to the results of previous studies, and in the case of fish, the dominant species were found to be Toadfish and Croaker. Using the validated model, we predicted the transient or continuous inflow of herbicide components from the effluent of Hagut-duk, but phytoplankton and invertebrates decreased in both inflow situations. Exceptionally, copepods were not affected by the two inflow situations, and crabs continued to increase during temporary inflow conditions except for the initial stagnation period. All fish died in the continuous inflow situation, but in the temporary inflow situation, the Croaker increased and the Toadfish decreased.

Conclusions: The implementation of the Nakdong River Estuary ecosystem as an AQUATOX model was the first attempt in Korea. Through this study, a plan to predict various environmental changes that may occur in the future was prepared. It was confirmed that the introduction of herbicides suggested as an example of environmental change can have a fatal effect on the estuary ecosystem even in small amounts, and the foundation for ecosystem changes and future countermeasures to various environmental changes in the future was established.

Keywords: Nakdong Estuary, AQUATOX, Calibration, Chlorophyll-a, Nutrients 


\title{
연구논문
}

\section{AQUATOX 모델을 이용한 낙동강 하구역 생태계 모델 구축연구}

\author{
호앙티란안 $^{1 \odot} \cdot$ 응우엔트린 $^{1 \odot} \cdot$ 이준엽 $^{1 \odot} \cdot$ 한경수 $^{2} \cdot$ 이태윤 $^{1+\oplus}$ \\ ${ }^{1}$ 부경대학교 환경공학과 \\ ${ }^{2}$ 부경대학교 공간정보시스템공학과
}

목적 : 본 연구에서는 AQUATOX 모델을 이용하여 낙동강 하구역의 생태계를 표현하는 모델을 구축하고 측정 데 이터를 이용하여 생태계 모델을 검량하였으며, 검량된 모델을 이용하여 환경변화에 대한 낙동강 하구역 생태계 변 동을 예측하고자 하였다.

방법: US EPA에서 제공한 AQUATOX 모델을 이용하여 낙동강 하구역 생태계 모델을 구축한 후 낙동강 하구역에 대한 측정 데이터를 이용하여 모델을 검량하였다. 모델 검량은 측정된 클로로필-a에 대해 수행하였으며 $\mathrm{DO}$, 총질 소, 총인, 게, 새우, 어류 측정데이더를 검량된 모델에서 도출된 값과 비교하여 검증하였다. 최종 검증된 모델을 이 용하여 낙동강 상류에서 살충제 성분 $(0.4 \mathrm{ug} / \mathrm{L})$ 이 일시적 그리고 지속적으로 하구역으로 유입되었을 때 발생하는 생태계 변화를 예측하였다.

결과 및 토의: 측정된 클로로필-a에 대한 생태계 모델의 검량결과는 RB (0.029), F (1.35), RSME (0.489), MAE (0.105)였다. 하구역의 식물성 플랑크톤은 은편모조류, 돌말, 녹조, 남조류로 구성되었으며, 은편모조류의 경우에는 하구역을 서식지로 하여 성장하였지만 나머지 식물성 플랑크톤은 하굿둑 방류수를 통해 하구역으로 유입이 되었 다. 동물성 플랑크톤의 경우 요각류가 우점종이지만 방류수 유입 시 모두 해양으로 유출되는 것으로 밝혀졌다. 갑 각류의 경우 게와 새우가 우점종이었고 이들 모델값들은 기존 선행연구 결과와 유사하였으며, 어류의 경우에는 황 아귀와 달고기가 우점종으로 밝혀졌다. 검증된 모델을 이용하여 하굿둑 방류수로부터 제초제 성분이 일시적 혹은 지속적으로 유입이 되었을 경우를 예측하였는데, 식물성 플랑크톤과 무척추동물은 두가지 유입상황에서 모두 감소 하였다. 예외적으로 요각류는 두 유입상황에서 영향을 받지 않았고 게는 일시적 유입 상황에서는 초기 정체기를 제외하고는 지속적으로 증가하였다. 물고기는 지속적 유입상황에서는 모두 사멸하였으나, 일시적 유입상황에서는 Croaker는 증가하고 Toadfish는 감소하였다.

결론: 낙동강 하구역 생태계를 AQUATOX 모델로 구현한 것은 국내에서 처음으로 시도가 된 것으로 본 연구를 통 해 향후 발생 가능성이 있는 다양한 환경변화에 대해 미리 예측할 수 있는 방안을 마련하였다. 환경변화의 일례로 제시한 제초제의 유입은 적은 양이라도 하구역 생태계에 치명적 영향을 줄 수 있다는 것을 확인하였고 향후 다양 한 환경변화에 대한 생태계 변화 및 향후 대응방안을 마련할 수 있는 기반이 조성되었다.

주제어 : 낙동강 하구역, AQUATOX, 모델 검량, 클로로필-a, 영양물질

\section{1. 서론}

낙동강 하구역은 낙동강과 남해가 만나서 염분 구배가 발생 하는 전이 생태계로 분류되는 지역이다. 낙동강 하구역은 다 양한 생물들의 산란 및 서식처로 이용이 되며 자연재해 피해 저감, 오염물질 제거기능, 수산물 생산, 해상운송 등과 같은 다양한 생태적-사회경제적 가치를 지닌다고 할 수 있다. ") “철 새의 낙원"으로 알려진 낙동강 하구역은 주변의 대규모 개발 사업으로 인해 환경악화와 생태계 훼손 우려가 커지고 있다. 2000 년대 이후 낙동강 하구에서 진행된 개발사업은 녹산국가
공업단지, 신호일반산업단지, 화전일반산업단지, 및 부산 신 항만 개발사업이 있다. 이에 앞서 1983년 9월부터 1987년 11 월까지 진행된 낙동강 하굿둑 건설은 물의 교환율 감소, 염분 감소로 인해 수계환경에 큰 영향을 미치고 낙동강 상류에서 배출된 오염물질이 하굿둑으로 인해 해양으로 배출되지 못하 게 하여 수질악화 및 대규모 녹조현상(algal bloom)을 유발시 켰다. ${ }^{2)}$ 낙동강 하굿둑의 수문개폐에 따른 담수의 주기적 방출 은 하구역 수질, 생태계 및 지형변화에도 크게 영향을 미친다. 담수의 주기적 방출에 따른 하구역에서의 유속 변화와 염분 분포에 대한 연구와 하굿둑 방류량에 따른 하구역의 해양물리 
환경의 변화 연구를 통해 하굿둑 건설로 인한 하구역에 미치 는 영향을 파악할 수 있다.,4) 낙동강 하구역 지역에 대한 연구 는 방류수에 포함된 오염물질 및 식물성플랑크톤의 종류와 농도 규명, 하구역의 수질 및 퇴적토 오염도 평가, 하구역의 식물성플랑크톤, 동물성플랑크톤, 저서생물의 종 및 분포도 조사 등으로 구분이 된다.

낙동강 수계 주변에는 많은 산업시설이 위치해 있고 이들 시설은 산업폐수와 생활하수의 발생을 유발하고 이들 폐수는 인근 하천을 통해 최종적으로 해양으로 유입이 된다. 낙동강 하구역 수질에 영향을 주는 인자들은 상류지역으로부터의 비 점오염원 유입, 축산폐수 유입, 낙동강 중류지역의 하수처리 장 방류수 유입, 낙동강 하구 지역에서의 녹조발생 등이 있 다. ${ }^{5)}$ 산업폐수에 포함된 잔류성 유기물질의 경우 생태계 내에 서 잘 분해가 되지 않고 생물 내에 축적이 되어 최근 이에 대한 연구가 활발히 진행이 되고 있다. Perfluoroalkyl acids, polychlorinated biphenyl, polycyclic aromatic hydrocarbons 의 하구역 퇴적토에 축적된 농도를 규명하려는 연구가 있었고 산업시설과 인접한 곳에서는 우려할 수준의 오염물질이 검출 되었다. ${ }^{6-8)}$ 낙동강 하구역에서의 저서생태계에 대한 연구는 하굿둑 건설이전에는 체계적인 연구조사가 진행이 되지 않았 으나 건설 후에는 부영양화의 지표인 클로로필-a의 농도에 관한 연구, 장마기 탁도의 증가와 체류시간 감소로 인한 Chl-a, $\mathrm{TP}, \mathrm{TN}$ 의 농도 감소 및 수질향상 방안을 제시한 연구, 낙동강 플랑크톤 군집동태에 관한 연구, 식생분포에 관한 연구 등이 지속적으로 수행되었다. ${ }^{9-11)}$

수계로 유입된 영양물질과 독성물질은 수생태계에 직접 적 영향을 미치며 생물축적을 통해 상위영양단계로 이동하 여 최종적으로는 인간에게 영향을 미칠 수 있다. 기존의 수질 모델링 기법(QUAL2E, STREAM, WQRRS, WASP, EFDC, QUALKO)은 적정관리방안, 환경영향, 미래의 수질예측 등에 효과가 있으므로 수질관리정책에 유용하게 사용되어 왔다. 그러나, 이들 모델은 수생태계 내에서의 영양물질 및 독성물 질의 이동 및 생태계에 미치는 영향, 생물축적 현상 및 생태위 해성을 예측하기에는 한계가 존재한다. 이러한 생물농축 및
생태계 변화를 예측할 수 있는 수생태계 모델인 AQUATOX는 2002년 US EPA에서 처음 개발된 이후 2014년에는 3.1 버전이 발표되어 하구역 및 해양 생태계도 모델로 구현할 수 있게 되었다. 과거 멕시코만 원유유출 사고로 인한 해양생태계 및 하구역 생태계의 손상을 AQUATOX 3.1을 이용하여 정확히 예측한 사례가 있었다. ${ }^{12-15)}$

이에 본 연구에서는 수생태계 예측모델로 검증이 된 AQUATOX를 사용하여 낙동강 하구역을 정확히 설명할 수 있는 모델을 구축한 후 다양한 환경변화에 따른 낙동강 하구 역 내에서의 생태계 변화를 구현해보고자 한다. 낙동강 하구 역의 생태계 현황은 기존 연구자료를 수집하여 이를 입력변수 로 사용하고 초기 모델을 구축한 후 민감도 분석을 통해 검량 하고자 하는 대상에 가장 영향을 많이 주는 페러미터를 선정 하여 검량을 진행하고자 한다. 최종 검량은 낙동강 하구역에 서 측정된 각종 생태계 자료를 이용하여 수행하고, 검량된 모델을 이용하여 방류수에 제초제 성분이 포함된 경우에 하구 역 생태계 변화에 대해 예측하고자 한다.

\section{2. 실험재료 및 방법}

\section{1. 낙동강 하구역}

\subsection{1. 물리 ·화학적 특성}

연구 대상 지역 $\left(\right.$ 위도 $35^{\circ} 03^{\prime} \mathrm{N} \sim 35^{\circ} 06^{\prime} \mathrm{N}$; 경도 $128^{\circ} 50^{\prime} \mathrm{E} \sim$ $\left.128^{\circ} 57^{\prime} \mathrm{E}\right)$ 은 낙동강 하굿둑과 해양이 만나는 지점으로 남쪽 은 자연적으로 조성된 모래섬들이 위치하고 있다. 대상 지역 의 물리화학적 특성은 Table1에 요약하였다. Fig.1에 표시된 14 개 지점은 부산광역시에서 추진하는 낙동강하구 생태계 보 전과 관리를 위한 기초자료 확보를 위한 장기모니터링 연구사 업에서 설정한 시료채취 지점을 의미하며 이 연구의 자료를 토대로 모델의 초기값 설정, 모델 검량을 수행하였다. ${ }^{16)}$

\subsection{2. 생태학적 특성}

하구 생물의 공간분포는 염분과 퇴적상에 따라 크게 달라지 는데, ${ }^{17)}$ 이 중에서 염분이 하구에서의 대형저서동물군집에 큰

Table 1. The hydrological and physicochemical characteristics in Nakdong estuary.

\begin{tabular}{cccc} 
Hydrological characteristics & & \multicolumn{2}{c}{$\begin{array}{c}\text { Water physicochemical parameters } \\
\text { (averaged value) }\end{array}$} \\
Area $\left(\mathrm{km}^{2}\right)$ & 37.95 & $\mathrm{pH}$ & 8.1 \\
\hline Maximum length $(\mathrm{km})$ & 6.3 & $\mathrm{DO}(\mathrm{mg} / \mathrm{L})$ & 8.6 \\
\hline Maximum width $(\mathrm{km})$ & 10.5 & Salinity $(\mathrm{ppt})$ & 16.9 \\
\hline Mean depth $(\mathrm{m})$ & 3 & $\mathrm{BOD}^{(\mathrm{mg} / \mathrm{L})}$ & 1.6 \\
\hline Maximum depth $(\mathrm{m})$ & 5 & $\mathrm{COD}_{\mathrm{Mn}}(\mathrm{mg} / \mathrm{L})$ & 6.1 \\
\hline Mean evaporation $(\mathrm{cm} /$ year) & 43.18 & $\mathrm{TN}(\mathrm{mg} / \mathrm{L})$ & 1.5 \\
\hline Latitude $\left({ }^{\circ}\right)$ & 35.3 & $\mathrm{NO}_{3}{ }^{-}(\mathrm{mg} / \mathrm{L})$ & 3.8 \\
\hline Mean light intensity $(\mathrm{Ly} / \mathrm{d})$ & 162 & $\mathrm{TP}(\mathrm{mg} / \mathrm{L})$ & 0.05 \\
\hline Mean temperature $\left({ }^{\circ} \mathrm{C}\right)$ & 15 & $\mathrm{TSS}(\mathrm{mg} / \mathrm{L})$ & 13.6
\end{tabular}




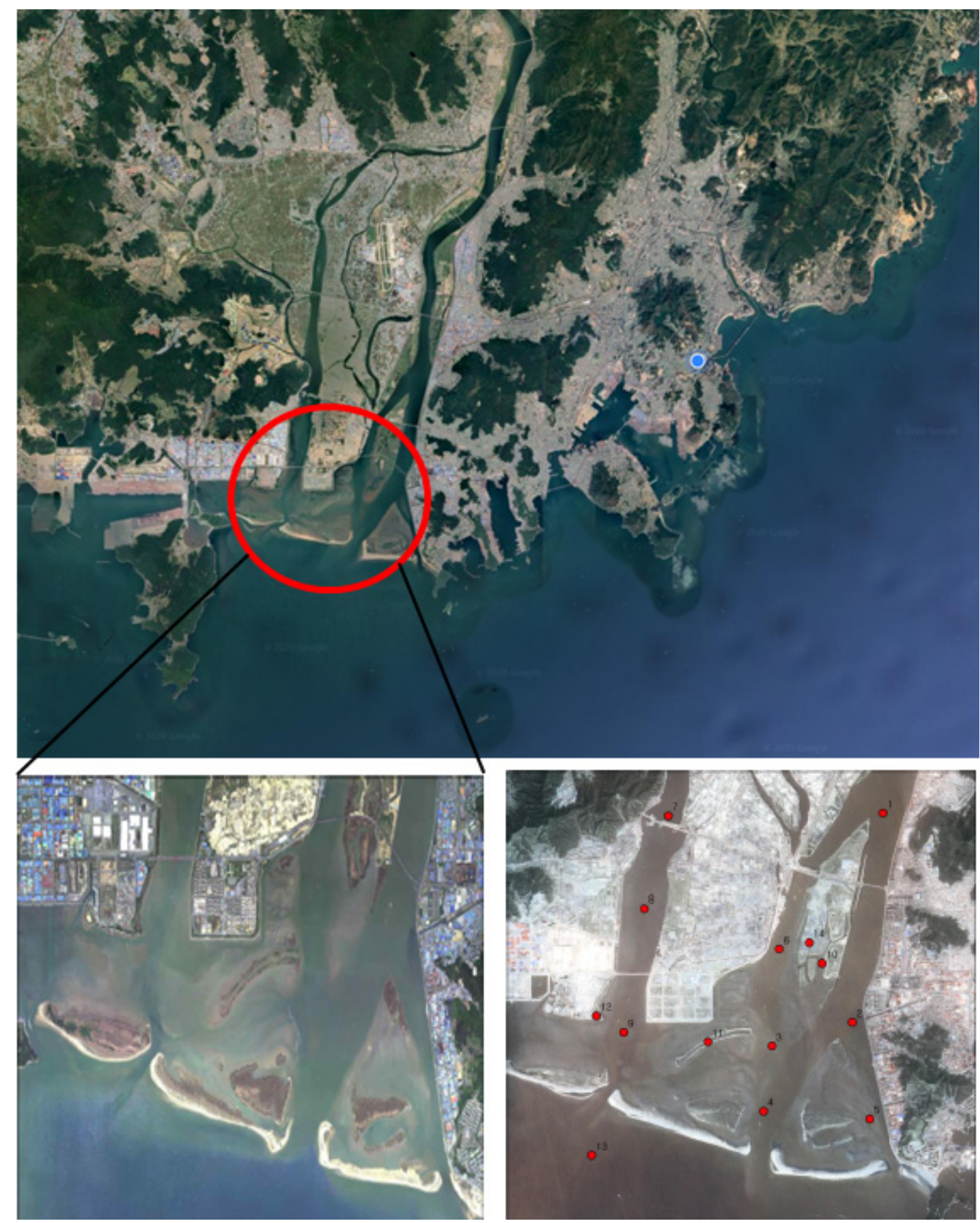

Fig. 1. Maps showing study sites of Nakdong estuary (Red dots represent sampling sites).

영향을 주는 것으로 확인되었다. ${ }^{18,19)}$ 낙동강 하굿둑 건설 이후 에는 지형의 변화로 인한 염분변동으로 인해 대형저서동물의 출현 종수가 건설이후에 크게 감소하였다. ${ }^{20)}$ 또한, 하굿둑 완 공 이후에는 소형 다모류인 P. membranacea, P. kempi이 우점 종으로 출현하였으며, 단각류인 S. sinensis도 출현하여 하굿둑 완 공으로 인해 낙동강 저서환경이 오염되고 있음을 알려주었다. ${ }^{20)}$

낙동강 하구역에 서식하는 식물플랑크톤의 시·공간분포 특성에 대한 연구가 진행이 되었으며, 이 연구를 통해 상부
수역(본 연구대상 지역과 일치)과 하부수역(본 연구대상 지 역의 남쪽 및 가덕도 오른쪽 지역)에 서식하는 우점종 식물 플랑크톤의 종류와 개체수를 밝혀내었다. ${ }^{21)}$ 식물성플랑크 톤의 개체수는 상부수역(평균 2,079 cells $/ \mathrm{mL}$ )이 하부수역(평 균 220 cells $/ \mathrm{mL}$ )보다 9배 이상 높았으며 상부수역은 돌말류 (Diatoms), 녹조류(Greens), 남조류(Blue-greens) 및 은편모류 (Cryptomonas)가 우점종이었다. 이에 반해 하부수역에서는 와편모류(Dinoflagellates)가 우점종으로 확인되었다. ${ }^{21)}$ 


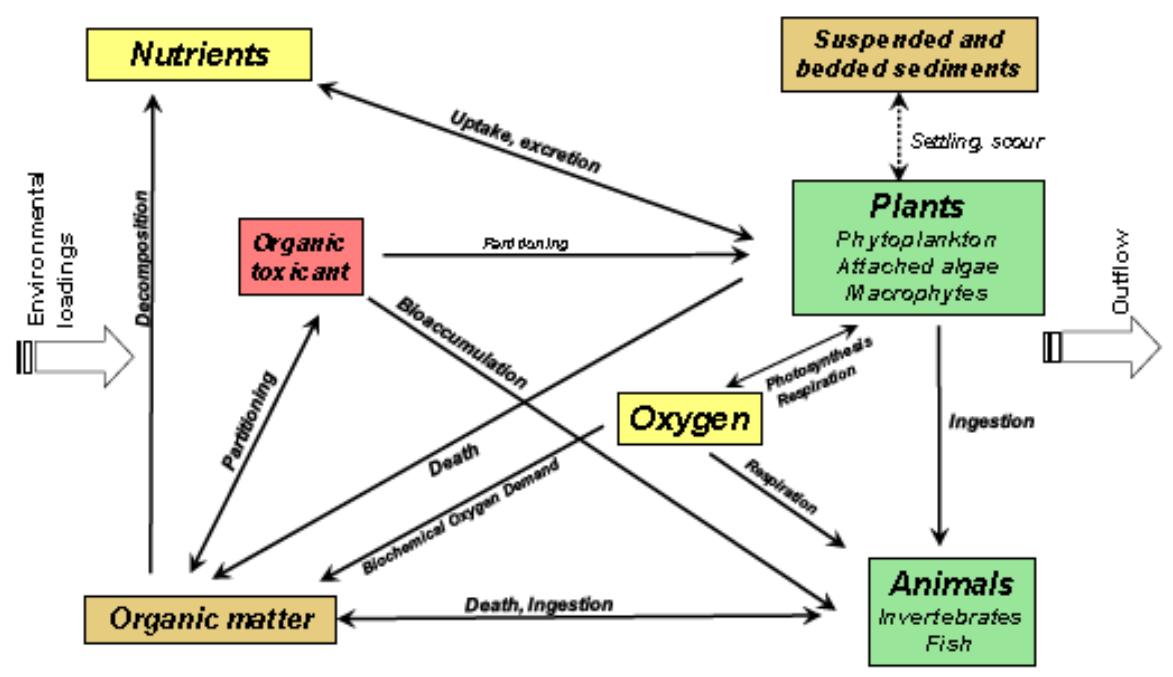

Fig. 2. Conceptual model of ecosystem represented by AQUATOX (adopted from US EPA).

\subsection{AQUATOX 모델}

\subsubsection{AQUATOX에 의해 표현된 생태계의 개념모델}

$\mathrm{AQUATOX}$ 는 2002년 US EPA에 의해 인과 질소와 같은 영양물질, TSS 유입, 유기오염물질 등의 유입으로 발생하는 수계의 수질변동과 수생태계의 영향을 예측하고 생태계에 대 한 위해성평가를 수행하기 위해 개발되었다. 수생태계에 포함 된 부착조류(periphyton), 식물성 플랑크톤(phytoplankton), 동 물플랑크톤(zooplankton), 거대조류(macrophytes), 무척추동 물(invertebrate), 어류(fish) 등을 수생태 먹이망(food web)으 로 구성하여 모델을 구성한 후 이 모델을 이용하여 생물축적 현상, 생물상, 동물상, 각 생물간의 인과관계를 수치해석 기법 으로 해석하게 된다. ${ }^{15)} \mathrm{AQUATOX}$ 는 유기오염물질, 인과 질 소와 같은 영양물질, 수온변화 등과 같은 다양한 환경적 변화 로 인해 발생할 수 있는 생태계 변화를 평가할 수 있으며, 유기물질의 증가, 수생생물체의 사멸과 생식활동으로 야기되 는 영양물질의 순환, 유기물질과 생물체의 분해로 발생되는 수중 용존산소의 변화, 유속 변화로 인한 동물 서식처의 변화 등 다양한 생태계 변화를 예측할 수 있다(Fig. 2).

AQUATOX 모델 내에서의 식물성 플랑크톤(phytoplankton) 의 생체변화량(biomass)은 아래와 같은 식으로 표시된다.

$$
\begin{aligned}
\frac{d \text { Biomass }_{\text {phyto }}=}{d t}= & \text { Loading }+ \text { Photosynthesis }- \text { Respiration } \\
& - \text { Excretion }- \text { Mortality }- \text { Predation } \pm \text { Sinking } \\
& \pm \text { Floating }- \text { Washout }- \text { Washin } \pm \text { Diffusion } \\
& +\frac{\text { Slough }}{3}
\end{aligned}
$$

여기서, $\mathrm{dBiomass} / \mathrm{dt}=$ 식물성 플랑크톤의 시간에 따른 생체량 변화 $\left(\mathrm{g} / \mathrm{m}^{3}\right)$; Loading = 경계조건을 통한 식물성 플랑크톤 유입 량 $\left(\mathrm{g} / \mathrm{m}^{3} \cdot \mathrm{d}\right)$; Photosynthesis = 식물성 플랑크톤의 광합성률 $\left(\mathrm{g} / \mathrm{m}^{3} \cdot \mathrm{d}\right)$; Respiration $=$ 용존산소 고갈 시 호흡을 통한 생체량 손실 $\left(\mathrm{g} / \mathrm{m}^{3} \cdot \mathrm{d}\right)$; Excretion $=$ 식물성 플랑크톤의 배설량 $\left(\mathrm{g} / \mathrm{m}^{3} \cdot\right.$ d); Mortality = 포식 외의 식물성 플랑크톤의 사망으로 인한 생체량 손실 $\left(\mathrm{g} / \mathrm{m}^{3} \cdot \mathrm{d}\right)$; Predation $=$ 포식으로 인한 생체량 손실 $\left(\mathrm{g} / \mathrm{m}^{3} \cdot \mathrm{d}\right)$; Washout $=$ 방류수 유입으로 인한 하류쪽으로의 세 척 $\left(\mathrm{g} / \mathrm{m}^{3} \cdot \mathrm{d}\right)$; Washin $=$ 상류쪽 세척으로 인한 모델내 유입 (linked segment version only, $\mathrm{g} / \mathrm{m}^{3} \cdot \mathrm{d}$ ); Sinking = 식물성 플랑 크톤의 침전으로 인한 손실 $\left(\mathrm{g} / \mathrm{m}^{3} \cdot \mathrm{d}\right) ;$ Floating = 식물성 플랑크 톤의 표면 부상으로 인한 상층부의 생체량 증가 혹은 하층부 의 생체량 감소; TurbDiff = 난류확산으로 인한 생체량 변화 $\left(\mathrm{g} / \mathrm{m}^{3} \cdot \mathrm{d}\right) ;$ Diffusion $_{\mathrm{seg}}=$ 두 모델간의 확산 이송으로 인한 생체 량 증가 혹은 감소 $\left(\mathrm{g} / \mathrm{m}^{3} \cdot \mathrm{d}\right)$; Slough $=$ 유속증가로 인한 세굴 현상을 통한 부착조류의 감소 또는 연계된 식물성 플랑크톤의 생체량 증가(부착조류의 부유로 인한 식물성 플랑크톤 생체량 증가)를 의미한다.

\subsubsection{AQUATOX에 사용된 변수(parameters)}

규조류, 녹조류, 남조류, 은편모조류 등의 식물성 플랑크톤 및 부착조류의 초기 생체량은 기존 연구 결과를 참고하였 고, ${ }^{20,21)}$ 거대조류, 동물성 플랑크톤, 저서무척추동물, 어류의 초기값은 모델내에 내장된 spin-up 기능을 사용하여 산정하였 다. 식물성 플랑크톤, 부착조류 및 거대조류의 생물학적 변수들 은 Table2에 정리하였다. 동물성 플랑크톤, 저서거대무척추동 물 및 물고기에 대한 생물학적 변수들은 Table3에 정리하였고 이들 값은 AQUATOX library에서 제공한 값들을 사용하였다.

\subsection{3. 민감도 분석(sensitivity analysis)}

민감도 분석은 모델에서 사용하는 많은 입력변수들이 결과 값에 어느 정도 영향을 주는 지를 평가하는 방법이다. 이 분석 을 통해 목표로 하는 대상값에 가장 영향을 많이 주는 입력변 수들을 순서대로 나열한 후 이 변수들 위주로 값을 바꾸어 검량을 수행하게 된다. AQUATOX에는 nominal range 민감도 분석 툴이 내장되어 있어 원하는 모든 입력변수들을 지정한 
Table 2. List of species and parameters used for producer populations (adopted from AQUATOX library).

\begin{tabular}{|c|c|c|c|c|c|c|}
\hline \multirow{2}{*}{ Population } & \multicolumn{4}{|c|}{ Phytoplankton } & \multirow{2}{*}{$\begin{array}{c}\text { Periphyton } \\
\text { Diatom, Marine }\end{array}$} & \multirow{2}{*}{$\begin{array}{c}\text { Macrophyte } \\
\text { Ruppia }\end{array}$} \\
\hline & Diatom & Green & Blue-green & Cryptomonas & & \\
\hline $\mathrm{B}_{0}$ & 0.023 & 0.027 & 0.035 & 0.038 & 0.0003 & 0.236 \\
\hline $\mathrm{Ls}_{\mathrm{s}}(\mathrm{Ly} / \mathrm{d})$ & 62 & 54 & 60 & 50 & 22.5 & 92.3 \\
\hline $\mathrm{K}_{\mathrm{P}}(\mathrm{mg} / \mathrm{L})$ & 0.06 & 0.05 & 0.03 & 0.05 & 0.055 & 0 \\
\hline $\mathrm{K}_{\mathrm{N}}(\mathrm{mg} / \mathrm{L})$ & 0.39 & 0.01 & 0.4 & 0.03 & 0.117 & 0 \\
\hline$T_{R S}$ & 1.8 & 2 & 2 & 2 & 1.8 & 3.1 \\
\hline $\mathrm{T}_{0}\left({ }^{\circ} \mathrm{C}\right)$ & 20 & 25 & 27 & 12 & 20 & 25 \\
\hline$P_{m}\left(d^{-1}\right)$ & 3.4 & 3.6 & 2.2 & 3.5 & 2.06 & 0.385 \\
\hline$R_{\text {resp }}\left(d^{-1}\right)$ & 0.08 & 0.03 & 0.05 & 0.026 & 0.026 & 0.22 \\
\hline$M_{c}\left(d^{-1}\right)$ & 0.01 & 0 & 0 & 0.01 & 0.001 & 0.001 \\
\hline$L_{e}\left(m^{-1}\right)$ & 0.14 & 0.14 & 0.09 & 0.144 & 0.03 & 0.22 \\
\hline W/D & 10 & 5 & 5 & 5 & 5 & 5 \\
\hline
\end{tabular}

$\mathrm{B}_{0}$ : initial biomass, $\mathrm{mg} / \mathrm{L}$ for phytoplankton and $\mathrm{g} / \mathrm{m}^{2}$ for periphyton and macrophyte; Ls: light saturation level for photosynthesis; $\mathrm{K}_{\mathrm{p}}$ : half-saturation constant for phosphorus; $K_{N}$ : half-saturation constant for nitrogen; $T_{R S}$ : temperature response slope, unitless; $T_{0}$ : optimal temperature; $P_{m}$ : maximum photosynthetic rate ; $R_{\text {resp }}$ : respiration rate; $M_{c}$ : mortality coefficient; Le: light extinction; W/D: wet and dry weight ratio.

Table 3. List of species and parameters used for consumer populations (adopted from AQUATOX library).

\begin{tabular}{|c|c|c|c|c|c|c|}
\hline \multirow{2}{*}{ Population } & \multicolumn{2}{|c|}{ Zooplankton } & \multicolumn{2}{|c|}{ Benthic macroinvertebrate } & \multicolumn{2}{|c|}{ Fish } \\
\hline & Copepod & Rotifer & Shrimp & Crab & Croaker & Toadfish \\
\hline $\mathrm{B}_{0}$ & 0.0013 & 0.0001 & 2.31 & 0.43 & 0.26 & 1.05 \\
\hline $\mathrm{H}_{\mathrm{S}}$ & 1 & 1 & 0.05 & 0.5 & 1 & 0.2 \\
\hline$C_{m}(g / g d)$ & 1.8 & 3.44 & 0.18 & 0.098 & 0.075 & 0.33 \\
\hline$P_{\min }(m g / L)$ & 0.25 & 0.6 & 0.05 & 0.1 & 0.05 & 0.5 \\
\hline $\mathrm{T}_{0}\left({ }^{\circ} \mathrm{C}\right)$ & 26 & 25 & 28 & 34 & 25 & 30 \\
\hline $\mathrm{R}_{\text {resp }}\left(\mathrm{d}^{-1}\right)$ & 0.01 & 0.34 & 0.019 & 0.008 & 0.005 & 0.002 \\
\hline$C_{c}$ & 8 & 2.5 & 20 & 10 & 10 & 4 \\
\hline$M_{c}\left(d^{-1}\right)$ & 0.027 & 0.1 & 0.002 & 0.001 & 0.0012 & 0.012 \\
\hline $\mathrm{L}_{f}$ & 0.05 & 0.05 & 0.05 & 0.05 & 0.05 & 0.07 \\
\hline W/D & 5 & 5 & 5 & 5 & 5 & 5 \\
\hline
\end{tabular}

$\mathrm{B}_{0}$ : initial biomass, $\mathrm{mg} / \mathrm{L}$ for zooplankton and fish and $\mathrm{mg} / \mathrm{m}^{2}$ for benthic animal; $\mathrm{H}_{\mathrm{s}}$ : half-saturation feeding, $\mathrm{mg} / \mathrm{L}$ for zooplankton and fish and $\mathrm{g} / \mathrm{m}^{2}$ for benthic animal; $C_{m}$ : maximum consumption rate; $P_{\text {min }}$ : minimum prey for feeding; $T_{0}$ : optimal temperature; $R_{\text {resp }}$ : endogenous respiration rate; $C_{c}$ : carrying capacity, $\mathrm{mg} / \mathrm{L}$ for zooplankton and fish and $\mathrm{g} / \mathrm{m}^{2}$ for benthic animal; $\mathrm{M}_{\mathrm{c}}$ : mortality coefficient; $\mathrm{L}_{\mathrm{f}}$ : initial lipid fraction; W/D: wet and dry weight ratio.

후 목표(예: 클로로필-a)를 최종 선택한 후 민감도 분석을 수행 하게 된다. 민감도 값은 아래의 식에 따라 계산되어진다.

$$
\begin{aligned}
\text { Sensitivity }= & \frac{\mid \text { Result }_{\text {Pos }}-\text { Result }_{\text {bas }}|+| \text { Result }_{\text {Ng }}-\text { Result }_{\text {bas }} \mid}{2 \times \mid \text { Result }_{\text {baseline }} \mid} \\
& \cdot \frac{100}{\text { Pct Changed }}
\end{aligned}
$$

여기서, 민감도(sensitivity) = 정규화된 민감도 통계(normalized sensitivity statistic) (\%), Result Pos $=$ 입력변수의 증가 시 AQUATOX의 평균값, Result $\mathrm{Ng}_{\mathrm{Ng}}=$ 입력변수의 감소 시 AQUATOX의 평균값, Result baseline $=$ 입력변수의 변동이 없는 상태의 AQUATOX의 평균값; PctChanged = 입력변수의 \% 변화량을 의미한다.

민감도 분석에서는 선정된 입력변수 값을 $\pm 10 \%$ 변화시켜서
결과값에 주는 영향을 밝혀내며, 모델링 기간은 2016년 1월 13일부터 2020년 1월 31일로 약 4년의 기간을 대상으로 한다. 낙동강 하구역은 하굿둑으로부터 주기적으로 방류되는 수량 이 많기 때문에 식물, 동물, 물고기와 관련된 입력변수 외에 방류수에 포함된 규조류, 녹조류와 같은 식물성 플랑크톤의 유입량, 영양염류 농도, TSS와 같은 변수들도 민감도 분석에 포함된다. 민감도 분석에 사용된 변수들은 Table4에 요약되 어 있다.

\subsection{4. 모델 검량(calibration) 및 검증(validation)}

구축된 모델에 대한 검량은 기존 낙동강 하구역 측정자료를 이용하였으며, 물리·화학적 입력값(DO, TSS, 영양염류, 클로 로필-a, $\mathrm{pH}$, 온도, $\mathrm{BOD}, \mathrm{COD}$ 등)은 부산연구원 연차보고서를 
참고하였다. ${ }^{10}$ 식물성플랑크톤의 종 및 개체술), 그리고 저서 생물 ${ }^{20}$ 에 대한 자료는 모델의 초기값에 사용이 되었고 모델 검량 후 모델 검증에도 사용을 하였다.

먼저 민감도 분석을 통해 결과값에 영향을 주는 변수들을 선정한 후 이들 변수들을 변화시켜 결과값과의 일치여부를 통해 검량을 수행하였고 검량에 사용된 변수들은 Table4에 요약되어 있다. 검량에 사용된 목표값 및 측정값은 클로로필-a 농도값이었고 동물성 플랑크톤, 저서거대무척추동물, 물고기 의 경우에는 측정값이 많지 않아 정성적 평가가 이루어졌다. 검량의 정확성 평가는 상대편향도(relative bias) ${ }^{22)}$ 기법을 이 용했으며 아래와 같이 표현된다.

$$
\mathrm{rB}=\left(\operatorname{Pred}_{\mathrm{Bar}}-\mathrm{Obs}_{\mathrm{Bar}}\right) / \mathrm{S}_{\mathrm{obs}}
$$

여기서, $\mathrm{rB}$ 는 상대편향도(표준편차 단위), $\mathrm{Pred}_{\mathrm{Bar}}$ 는 모델값의 평균값, $\mathrm{Obs}_{\mathrm{Bar}}$ 는 관측값의 평균값, 그리고 $\mathrm{S}_{\mathrm{obs}}$ 는 관측값의 표준편차를 의미한다.

두 번째 기법은 F-test를 이용하여 검량의 정확도를 예측하 는 것으로 모델값의 분산과 측정값의 분산의 비를 의미한다. F-test 값이 1 이라는 것은 모델값과 측정값의 분산비가 1 이라 는 것을 나타낸다. F-test는 다음과 같이 표현된다.

$$
F=\frac{\left(\operatorname{Var}_{p r e d}\right)}{\operatorname{Var} \text { obs }}
$$

여기서, $\operatorname{Var}_{\mathrm{pred}}$ 는 모델값의 분산, $\operatorname{Var}_{\mathrm{Obs}}$ 는 측정값의 분산을 의미한다.

Root mean square error (RMSE)와 mean absolute error (MAE)도 모델링 연구에서 모델검량에 자주 사용되는 통계기 법으로 본 연구의 모델 검량의 정확도 평가에 사용되었으며, 아래와 같이 표시된다.

$$
\begin{aligned}
& \text { RSME }=\sqrt{\frac{1}{n} \sum^{n}=1}(O i-P i)^{2} \\
& M A E=\frac{1}{n} \sum^{n}=1|O i-P i|
\end{aligned}
$$

여기서, $\mathrm{Oi}$ 는 측정값, $\mathrm{Pi}$ 는 모델값을 나타낸다. RSME와 $\mathrm{MAE}$ 의 값이 0 에 가까울수록 모델값과 측정값과의 일치도가 증가 함을 의미한다.

\section{3. 실험결과 및 해석}

\section{1. 민감도 분석}

민감도 분석 결과는 Fig.3에 토네이도 도표로 표시하였다. 토네이도 도표에서 붉은색 선은 해당 변수를 $-10 \%$ 감소시켰 을 때 클로로필-a의 변화를 의미하고, 푸른색 선은 해당 변수 를 $+10 \%$ 증가시켰을 때 클로로필-a의 변화를 나타낸다. 민감 도 $100 \%$ 는 해당 변수를 $10 \%$ 변화시켰을 때 클로로필-a의 농도도 $10 \%$ 변화하는 것을 의미한다. 민감도 값이 크다는 것 은 해당 변수가 클로로필-a의 농도 변화에 크게 영향을 미친 다는 것을 뜻한다. 민감도 분석은 변수들을 3 가지로 분류하여 수행하였는데, 물리적 특성(수온, $\mathrm{pH}$, 빛, 바람, 유입수량), 영양물질(COD, 부유 및 용존 유기물, TSS, 질소, 인, 염분), 그리고 생물체 관련 변수에 대해 각각 민감도 분석을 수행하 였다(Fig.3). 민감도 분석에 사용된 변수들은 Table4에 요약 하였다.

물리적 특성에 관련된 변수들 중 유입수량의 변화가 클로로필 -a의 변화에 가장 민감한 것으로 나타났으며(민감도 $32.3 \%$ ) 그 외 변수들의 경우 클로로필-a의 변화에 큰 영향을 주지

\begin{tabular}{|c|c|c|}
\hline Producers (units) & Consumers (unit) & Driving variables (unit) \\
\hline Saturating light $(\mathrm{Ly} / \mathrm{d})$ & Half saturation feeding $(\mathrm{mg} / \mathrm{L})$ & Temperature $\left({ }^{\circ} \mathrm{C}\right)$ \\
\hline$P$ half saturation (mg/L) & Maximum consumption (g/g d) & $\mathrm{pH}$ \\
\hline $\mathrm{N}$ half saturation (mg/L) & Temperature response slope & Light (Ly/d) \\
\hline Temperature response slope & Optimal temperature $\left({ }^{\circ} \mathrm{C}\right)$ & Wind $(\mathrm{m} / \mathrm{s})$ \\
\hline Optimal temperature $\left({ }^{\circ} \mathrm{C}\right)$ & Maximum temperature $\left({ }^{\circ} \mathrm{C}\right)$ & Water volume $\left(\mathrm{m}^{3}\right)$ \\
\hline Maximum photosynthetic rate $(1 / d)$ & Endogenous respiration $(1 / d)$ & $\mathrm{TN}, \mathrm{NO}_{3}^{-}, \mathrm{TP}$ \\
\hline Photorespiration coefficient $(1 / d)$ & Excretion: Respiration & $\mathrm{CO}_{2}, \mathrm{DO}, \mathrm{TSS}, \mathrm{COD}$, Salinity, Detritus \\
\hline Respiration rate at $20^{\circ} \mathrm{C}(\mathrm{g} / \mathrm{g} \mathrm{d})$ & Gamete mortality (1/d) & \\
\hline Mortality coefficient (g/g d) & Mortality coefficient (/d) & \\
\hline Exponential mortality coefficient ( $\mathrm{g} / \mathrm{g} \mathrm{d}$ ) & Carrying capacity (g/sq m) & \\
\hline Light extinction $\left(1 / \mathrm{m}-\mathrm{g} / \mathrm{m}^{3}\right)$ & Mean wet weight & \\
\hline Carrying capacity $\left(\mathrm{g} / \mathrm{m}^{2}\right)$ & & \\
\hline
\end{tabular}
못하였다(Fig.3(a)). 영양물질과 관련된 변수들의 경우에는 $\mathrm{COD}$ 유입량을 $10 \%$ 감소시킬 때 클로로필-a의 민감도는 $66.9 \%$

Table 4. List of parameters that have been tested in model calibration and sensitivity analysis.

${ }^{\text {a } O n l y ~ f o r ~ m a c r o p h y t e ~}$ 

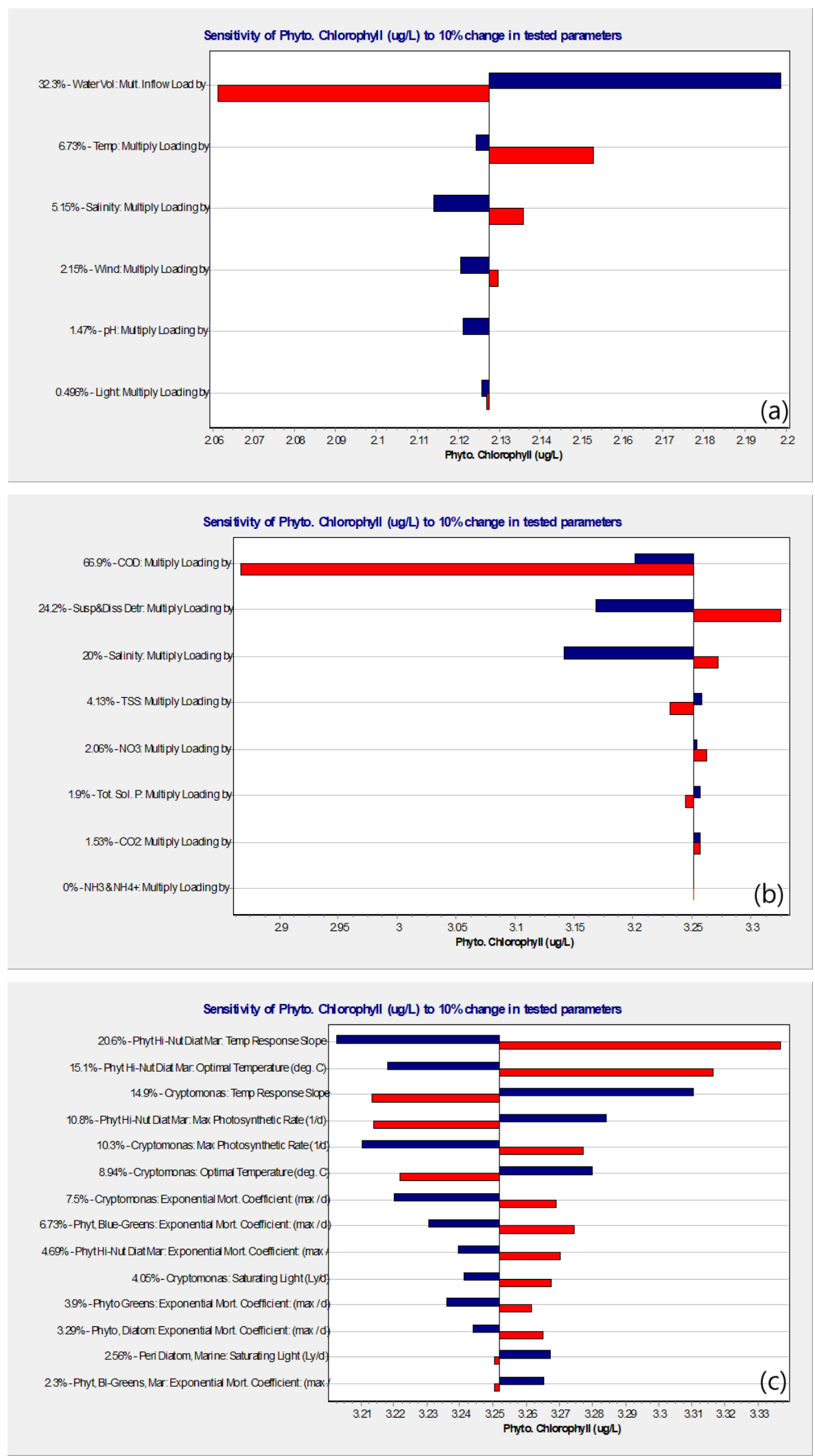

Fig. 3. Sensitivity of chlorophyll-a to $10 \%$ change in tested parameters in Nakdong estuary: (a) physicochemical parameter, (b) nutrients, (c) biological parameter. The black vertical line at the middle of the diagram represents the baseline model result in which no sensitivity test was conducted (i.e., Water Vol $=$ water volume, Temp $=$ temperature, Sus\&Diss Detr $=$ suspended and dissolved deteritus, Tot Sol. P. $=$ total soluble phosphate, Phyt Hi-NutDiatMar. $=$ phytoplankton hi nutrient diatom marine, Phyto Greens = phytoplankton greens). 

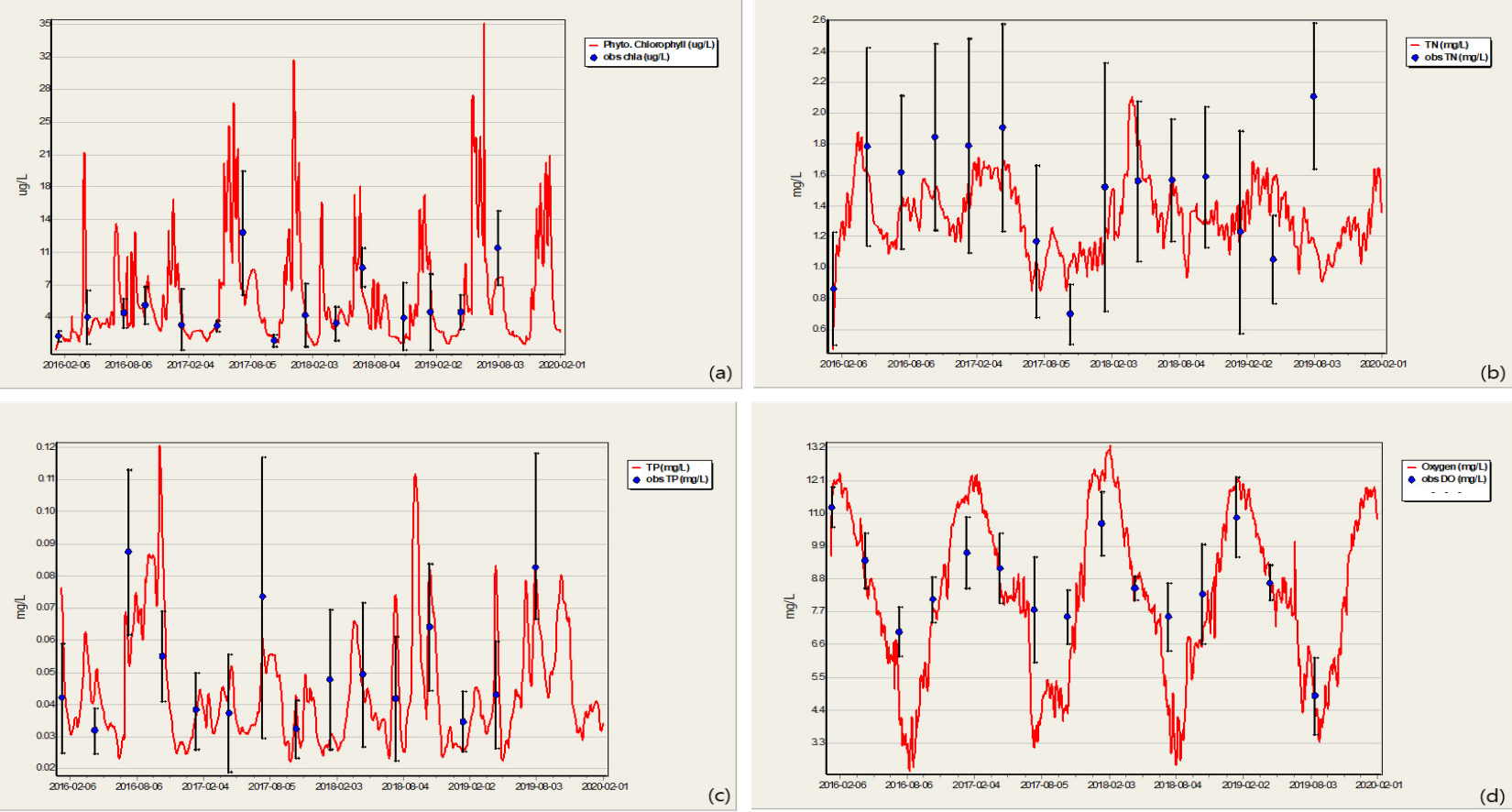

Fig.4. Observed (symbols) and calibrated AQUATOX simulations (lines) of (a) chlorophyll-a, and validation results of calibrated AQUATOX simulations for (b) TN, (c) TP, and (d) DO (i.e., Phyto. Chlorophyll = phytoplankton chlorophyll, obs chla = observed chlorophyll, obs TN = observed TN, obs TP = observed TP, obs DO = observed DO).

로 가장 크게 나타났고, $\mathrm{AQUATOX}$ 에서 $\mathrm{CBOD}_{5}$ 로 표시되는 부유 및 용존 유기물에 대해서는 클로로필-a의 민감도는 $24.2 \%$ 였다. 염분값의 경우에는 클로로필-a의 민감도는 $20 \%$ 였고 나머 지 TSS, 질산성 질소, 암모니아성 질소, 총인, 이산화탄소 등은 클로로필-a의 변화에 주는 영향은 미미하였다. 해양규조류인 Phyt Hi-Nut Diat Mar의 온도반응기울기(Temperature response slope)와 최적온도(optimal temperature)에 대한 클로로필-a의 민감도는 각각 $20.6 \%$ 와 $15.1 \%$ 로 가장 높았고, 다음은 은편모 조류(Cryptomonas)의 온도반응기울기(temperature response slope)가 민감도 $14.9 \%$ 를 나타내었다.

\section{2. 모델 검량 및 검증}

민감도 분석 결과에 따라 클로로필-a에 영향을 주는 변수 들을 변화시켜 모델 검량을 수행하였다. 클로로필-a에 대한 측정값과 모델값은 Fig.4(a)에 표시하였고 나머지 TN, TP, $\mathrm{DO}$ 에 대한 추가 검량은 하지 않았다. 따라서, Fig.4(a)를 제 외한 나머지 세 변수에 대한 결과는 클로로필-a에 대한 검량 이 끝난 후 이 검량된 모델을 구동하여 결과값을 도출하고 이를 측정값과 비교한 것이다. 모델값과 측정값과의 정확성 을 판별하기 위한 통계 값들은 Table5에 정리하였다. RB 값 은 0.018-0.365, F 값은 0.65-1.76, RSME 값은 0.018-1.134, 그리고 MAE 값은 0.003-1.143의 범위를 보여주었고, $\mathrm{TN}$ 의 경우는 다른 변수 $(\mathrm{TP}, \mathrm{DO})$ 들에 비해 검증 정확도가 낮은 것 으로 나타났다.
Table 5. Values of the goodness-of-fit criteria computed for the simulated variables during the calibration phase.

\begin{tabular}{ccccc} 
Variables & RB & $F$ & RSME & MAE \\
Chlorophyll-a & 0.029 & 1.35 & 0.489 & 0.107 \\
\hline TN & 0.365 & 0.65 & 0.363 & 0.143 \\
\hline TP & 0.176 & 1.21 & 0.018 & 0.003 \\
\hline DO & 0.018 & 1.76 & 1.134 & 0.029 \\
\hline
\end{tabular}

\section{3. 하구역 생태계}

\subsection{1. 식물성 플랑크톤(phytoplankton)}

낙동강 하구역의 4년간 식물성 플랑크톤의 변화 양상과 하굿둑의 방류량 자료는 Fig.5(a)에 나타내었다. 해당 기간 동안 은편모조류(Cryptomonas)가 우점종이었으며 다음으 로 녹조류(Greens), 돌말류(Diatoms), 남조류(Blue-greens) 그리고 와편모류(Dinoflagellate) 순이었다. 이들 플랑크톤은 지속적인 성장이 아닌 피크형태로 특정 기간 동안 단편적으 로 성장이 되는 것을 확인할 수 있는데, 이는 하굿둑 방류로 인한 염분변화와 방류수에 포함된 담수 플랑크톤의 유입때 문으로 알려져있다. ${ }^{21)}$ 2013년부터 2015년까지의 낙동강 하 구역 연구에 따르면 하굿둑에 가까운 곳에서는 담수 돌말류 인 Stephanodiscus spp.와 Synedra acus 가 출현하였고, 염분 이 높은 하구에서는(본 연구지역 남쪽 외측) Prorocentrum donghaiense, Gymnodinium spp. Cochlodinium polykrikoides 와 같은 와편모류가 주로 출현한 것으로 보고되었다. ${ }^{21)}$ 본 

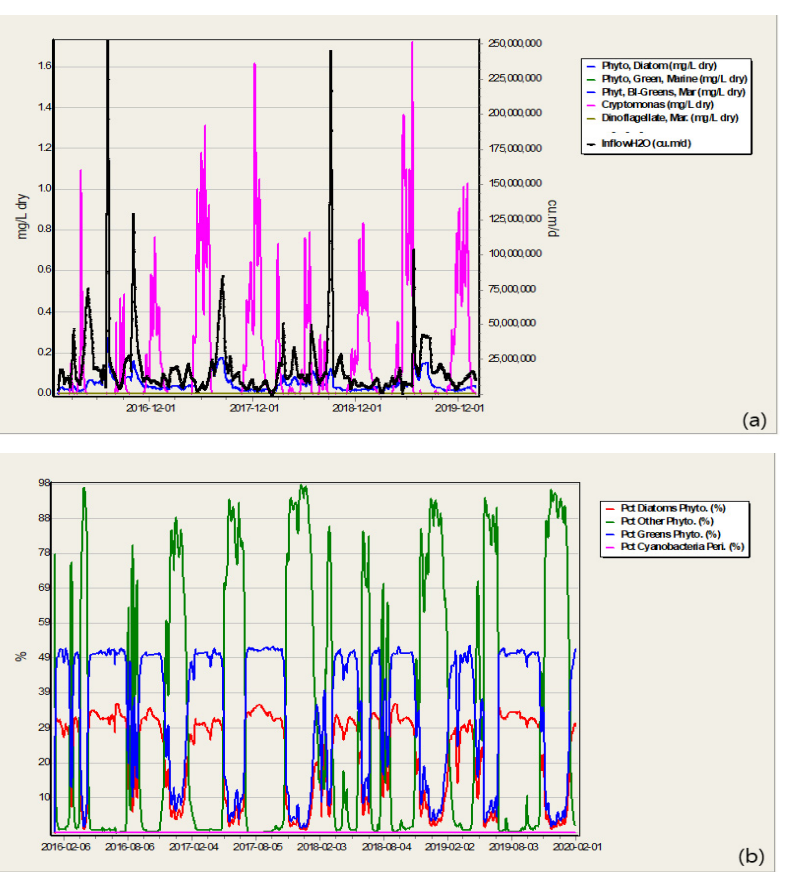

Fig. 5. Simulation results using calibrated AQUATOX model on Nakdong estuary for (a) variations of phytoplankton species and (b) percent component ratio of each species (i.e., phyto. $=$ phytoplankton, $\mathrm{Mar}=$ marine, $\mathrm{Pct}=$ percent, Peri. $=$ periphyton).

연구지역은 담수와 해수가 혼합이 되는 저염분 지역이라 와 편모류는 성장하지 않는 것으로 판단된다(Fig.5). 하굿둑 방 류량이 많은 시기에는 은편모조류의 농도는 급격히 줄었고, 반면 녹조류, 돌말류, 남조류의 농도가 급격히 증가하였는데 이는 하굿둑 내측의 낙동강 담수에 서식하는 플랑크톤의 유 입이 있었기 때문이다. ${ }^{20,21)}$ 2016년 3월부터 5월까지 기간에 는 하굿둑 방류량이 많았고 이때 플랑크톤의 구성비는 녹조 류 51\%, 돌말류 $31 \%$, 그리고 은편모조류는 $0 \%$ 였다. 2016년 6월과 7월에는 방류량이 최소였고 이때 은편모조류는 $92 \%$ 였고 나머지 플랑크톤은 $8 \%$ 이하였다(Fig.5(b)). 따라서, 은 편모조류는 대상지역에서 실제 발생하여 성장하는 플랑크 톤이고 나머지 플랑크톤(녹조류, 돌말류, 남조류)은 하굿둑 방류수를 통해 하구역으로 유입이 된 것으로 판단된다.

\subsection{2. 동물성 플랑크톤(zooplankton)}

동물성 플랑크톤은 2017년 7월, 2019년 7월에 급격히 증가 하였으나 대부분의 기간에는 성장을 하지 못하는 것으로 판단된다(Fig. 6(a)). 이는 하굿둑 방류량과 민접한 관계를 가지게 되는데 방류량이 많은 시점에서는 모든 동물성 플랑크 톤이 하류로 유실되고 성장이 가능한 시점은 방류량이 최저인 시점이라고 할 수 있다. 2015년 하구역의 동물성 플랑크톤 연구를 보면 5 월과 10 월에 각각 $0.078 \mathrm{mg} / \mathrm{L}$ 와 $0.124 \mathrm{mg} / \mathrm{L}$ 의 농도를 보여주었다. 22) 이때, 우점종은 요각류 성체(copepods), 지각류(cladocerans), 유공충류(foraminiferans), 야광충(Noctiluca scintillans) 등이었다. 본 연구에서는 2017년 7월에 요각류 농도 가 $0.04 \mathrm{mg} / \mathrm{L}$ 였는데 이는 위의 연구결과보다 낮은 것으로 보인 다. 이는 위의 연구에서 측정한 값들은 11 개 지역의 평균값을 사용하였는데, 이때 본 연구와 겹치는 지역은 2 군데였다. 따라 서, 위의 연구결과는 본 연구의 검량에는 사용될 수 없고 정성적 평가자료로만 사용이 되었다.

\subsection{3. 갑각류(Crustacea)}

게와 새우에 대한 모델 결과값은 Fig. 6(b)에 표시하였다. 게의 경우 초기에 높은 값을 가졌으나 이후 점차 안정적인 값을 보여주었고 새우의 경우에는 계절적 변동이 심한 것으로 나타났다. 기존 연구에 따르면 낙동강 하구역에서 발견된 게 중 우점종은 점박이꽃게(Portunus sanguinolentus)이며 이 지 역의 게의 농도는 $0.145 \mathrm{~g} / \mathrm{m}^{2}$ 으로 본 연구와 크게 차이가 없음 을 알 수 있다. ${ }^{23)}$ 새우의 경우에는 그라비새우(Palaemon gravieri), 꽃새우(Trachysalambria curvirostris), 남방도화새우 (Pandalus gracilis)가 주로 발견되었으며, 이 새우들의 농도는
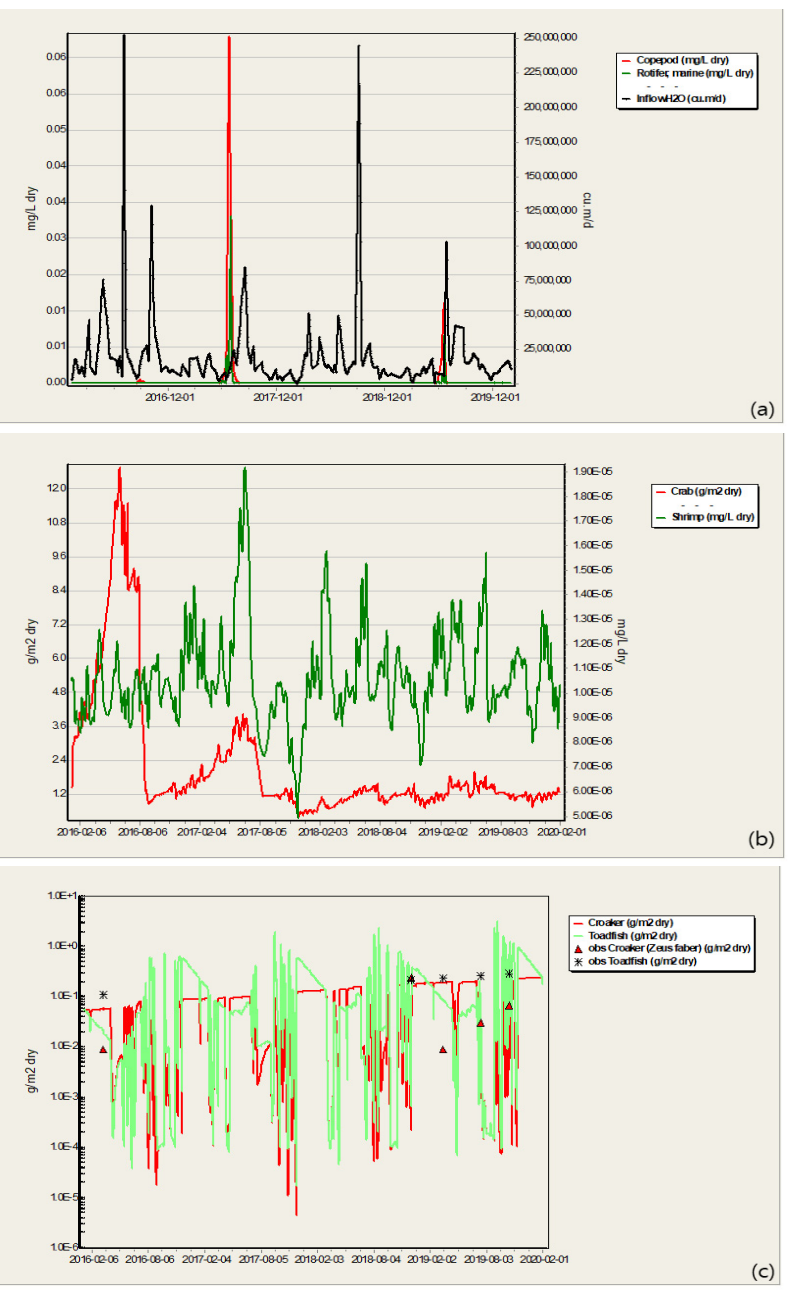

Fig.6. Simulation results using calibrated AQUATOX model on Nakdong estuary for (a) zooplankton, (b) crustacea, and (c) fish (i.e., inflow $\mathrm{H}_{2} \mathrm{O}=$ inflow of $\mathrm{H}_{2} \mathrm{O}$, obs = observed). 

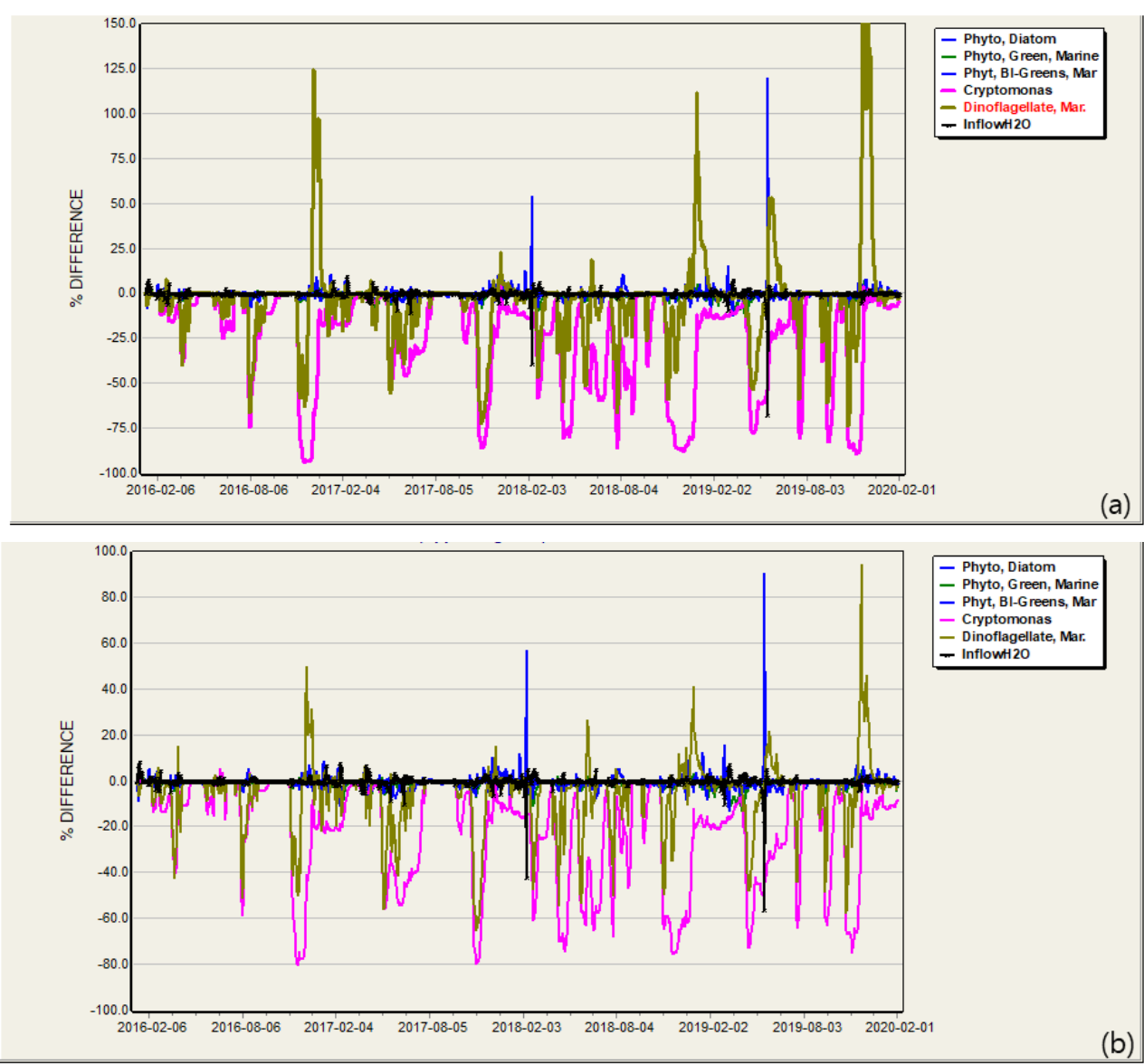

Fig. 7. Simulation results for \% difference of phytoplankton using calibrated AQUATOX model on Nakdong estuary when 0.4 $\mathrm{ug} / \mathrm{L}$ of chlorpyrifos was added as (a) spike loading and (b) constant loading (i.e., Phyto. = phytoplankton, Mar $=$ marine).

$1.0 \times 10^{-6} \mathrm{mg} / \mathrm{L}$ 였다. 본 연구에서 도출한 새우의 평균 농도는 $1.0 \times 10^{-5} \mathrm{mg} / \mathrm{L}$ 로 위의 측정값보다 높았다.

\subsection{4. 어류(Fish)}

낙동강 하구역에 서식하는 우점어류에 대한 조사(2007년 3월, 2010년 3월, 7월, 10월)를 통해 달고기(Zeus faber)와 황아 귀(Lophius litulon)가 우점종으로 확인되었다. ${ }^{23)}$ 이 지역은 본 연구지역보다 남쪽으로 약 $5 \mathrm{~km}$ 지점에 위치하고 있고 2007 년에서 2010년도의 자료이기 때문에 위 선행연구의 결과 를 본 연구의 모델의 검량에는 사용할 수가 없었지만 정성 적인 평가를 통해 모델의 정확성을 판단하고자 하였다. 따 라서, 2007년 자료는 2016년, 2010년은 2019년 자료로 가정 하여 Fig.6(c)에 삽입하였다. 모델의 Croaker와 Toadfish의 평균 생체량은 $0.01 \mathrm{~g} / \mathrm{m}^{2} \cdot \mathrm{d}$ 와 $0.02 \mathrm{~g} / \mathrm{m}^{2} \cdot \mathrm{d}$ 로 기존 측정값과 유사한 값임을 알 수 있었다.

\section{4. 생태계 변동 예측}

본 연구를 통해 구축된 낙동강 하구역 생태계모델을 이용하 여 가상의 환경변화에 따른 낙동강 하구역 생태계의 변화를 예측하였다. 기존 낙동강 중권역 대표지점 및 공단 배출수에
서의 준휘발성유기화합물 분포 특성에 대한 조사를 보면 2,4-Dinitrophenol이 조사기간 중 가장 검출빈도수가 높았고 chlorpyrifos의 경우 조사기간 중 검출되지 않았다. ${ }^{24)}$ 하지만, chlorpyrifos의 경우 1999 년 아산만과 경기만 해역의 잔류농 약 조사에 따르면 높은 농도는 아니지만 모든 해역에서 검출 이 되었다. ${ }^{25)}$ chlorpyrifos는 가정이나 가축의 해충구제 목적 및 과수원 해충방제 목적으로 세계적으로 널리 사용되는 물 질이며, 경구, 호흡 및 피부를 통해 빠르게 흡수가 되어 주로 체지방 및 지방 조직에 축적이 된다. 비록 내륙에서 유출된 chlorpyrifos는 낮은 용해도 $\left(\log \mathrm{K}_{\mathrm{ow}}=4.7\right)$ 로 인해 지하수나 지표수로의 이동은 제한될 것이나 집중호우나 기타 자연재해 로 인해 많은 양이 낙동강으로 유출될 가능성은 존재한다. 이 에 본 연구에서는 chlorpyrifos가 초기 농도 $0.4 \mathrm{ug} / \mathrm{L}$ 로 2016년 1월 13일부터 지속적으로 유입이 되는 경우와 2016년 1월 13 일 1 일 동안 하구역으로 유입이 되는 경우를 가정하여 생태계 변동을 확인하고자 하였다. 2016년 1월 13일의 방류수 유입량 은 3,557,606 m/ 3 였으며, chlorpyrifos에 대한 독성평가자료 는 AQUATOX 라이브러리에 내장된 자료를 보정하여 사용하 였다.

Fig.7에 chlorpyrifos의 유입으로 인한 식물성 플랑크톤의 

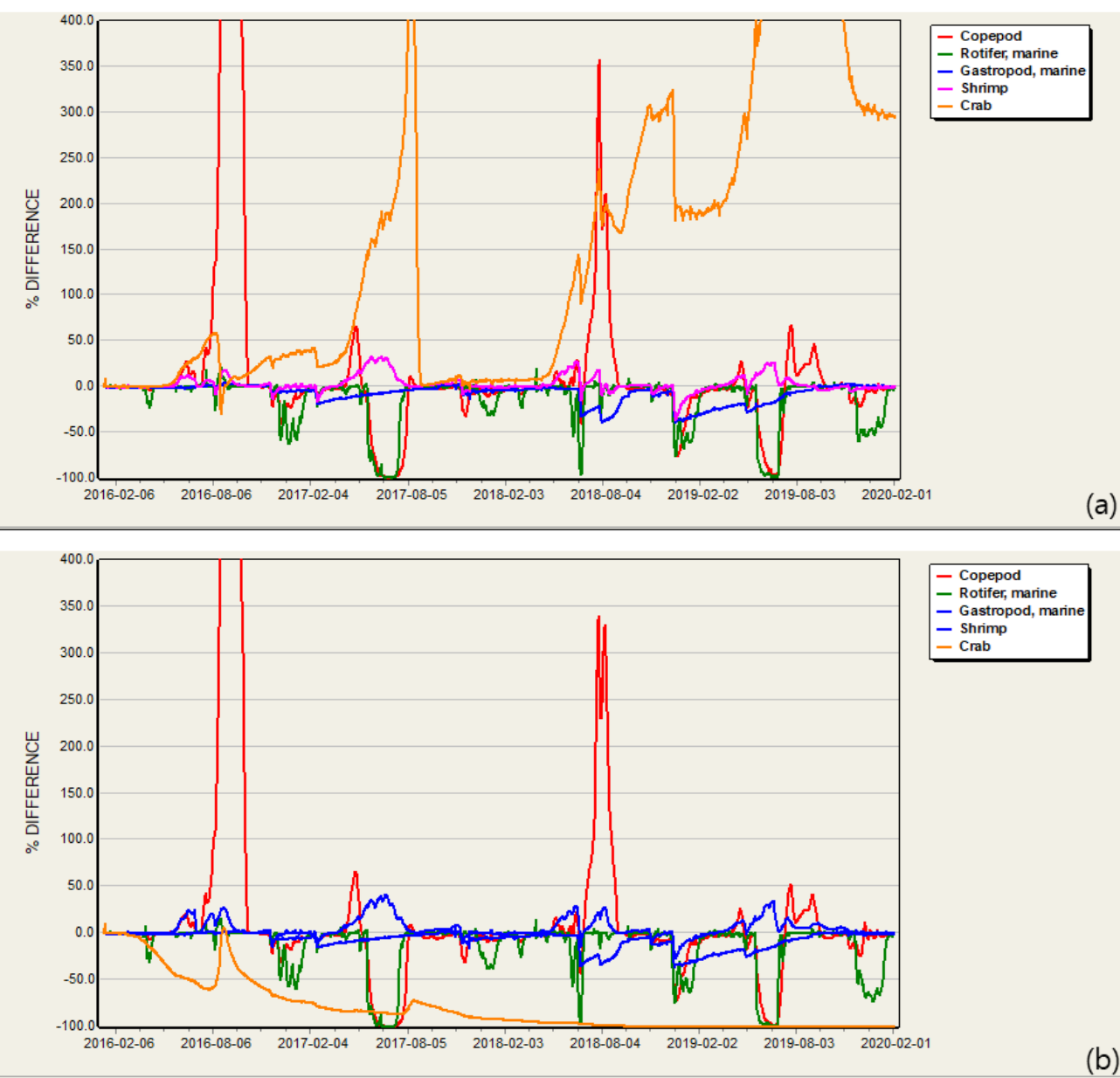

Fig. 8. Simulation results for \% difference of invertebrates using calibrated AQUATOX model on Nakdong estuary when 0.4 $\mathrm{ug} / \mathrm{L}$ of chlorpyrifos was added as (a) spike loading and (b) constant loading.

변화양상을 나타내었다. \% difference는 유입 후 결과에서 유입 이 없는 상태의 결과를 차감한 후 이 값을 유입이 없는 상태의 결과 값으로 나눈 값을 의미한다. 아무 변화가 없으면 \% difference는 0이 되고 생체량이 증가하면 \% difference는 양의 값을 가지게 된다. 일시적 유입과 지속적 유입의 경우에 플랑크 톤의 변화양상은 크게 차이가 없었다. 두 경우 모두 플랑크톤 의 농도는 감소하였으나, 2016년 11월, 2019년 1월, 2020년 1 월에는 와편모충류(Dinoflagellate)의 농도가 모두 증가하는 것을 볼 수 있었다. 은편모조류(Cryptomonas)의 경우 우점종 이었으나 chlorpyrifos의 유입 시 두 경우 모두 감소하였다. 무척추동물에 대한 결과는 Fig.8에 표시하였다. 요각류는 2016년 8월과 2018년 8월에 일시적 및 지속적 유입의 경우에 모두 크게 증가하였고, 게를 제외한 다른 무척추동물의 변화 양상은 크게 차이가 나지 않았다. 게의 경우 일시적 유입 시 2016년 8월까지 거의 증가하지 않았으나, 8월 이후 서서히 증가하기 시작하여 2017년 4월부터 급격히 증가한 후 2017년 8월 최대 생체량을 기록하였다. 이후 9월부터 감소하였다가 2018년 4월부터 다시 증가하기 시작하였다. 이에 반해 chlorpyrifos의 지속유입의 경우, 게는 지속적으로 감소하다
가 2016년 8월에 생체량 회복을 시작하였으나 이후 지속적으 로 감소하여 사멸하였다. 게의 chlorpyrifos에 대한 LC50은 $15.14 \mathrm{ug} / \mathrm{L}$ 로 요각류의 $5.8 \mathrm{ug} / \mathrm{L}$ 보다 크기 때문에 높은 농도에 보다 잘 적응할 수 있으나, 요각류보다 생체성장 주기가 길기 때문에 요각류에 비해 최대 성장시점이 늦은 것으로 판단된다 (Fig. 8(a)). 지속적 유입의 경우에는 게가 사멸한 반면 요각류 는 2016년 8월과 2018년 8월에 일시적 유입과 동일하게 크게 증가함을 알 수 있었다(Fig.8(b)). 이는 chlorpyrifos에 의한 직접적 독성효과 외에 먹이사슬의 관계에서 그 원인을 찾을 수 있다. 요각류는 식물성 플랑크톤과 유기물 입자를 주식으 로 하고 있으며, AQUATOX 먹이사슬에서는 다른 물고기의 먹이에 포함되지 않았다. 물고기의 경우 일시 유입(Fig. 9(a))의 경우에는 Croaker는 증가하고 Toadfish는 감소하였는 데, 이는 Croaker의 LC50 (1.86 ug/L)이 Toadfish의 LC50 (12.04 $\mathrm{ug} / \mathrm{L})$ 보다 작기 때문에 Toadfish가 증가하여야 한다. 하지만, 일시 유입의 경우에는 독성효과가 2016년 3월부터 없어졌기 때문에 Croaker의 증가와 Toadfish의 감소는 직접적인 독성효 과로 보기 어렵다. AQUATOX에서 제공하는 먹이사슬 자료를 통해 Croaker의 먹이 선호도는 쉽게 분해되는 유기물 퇴적물 

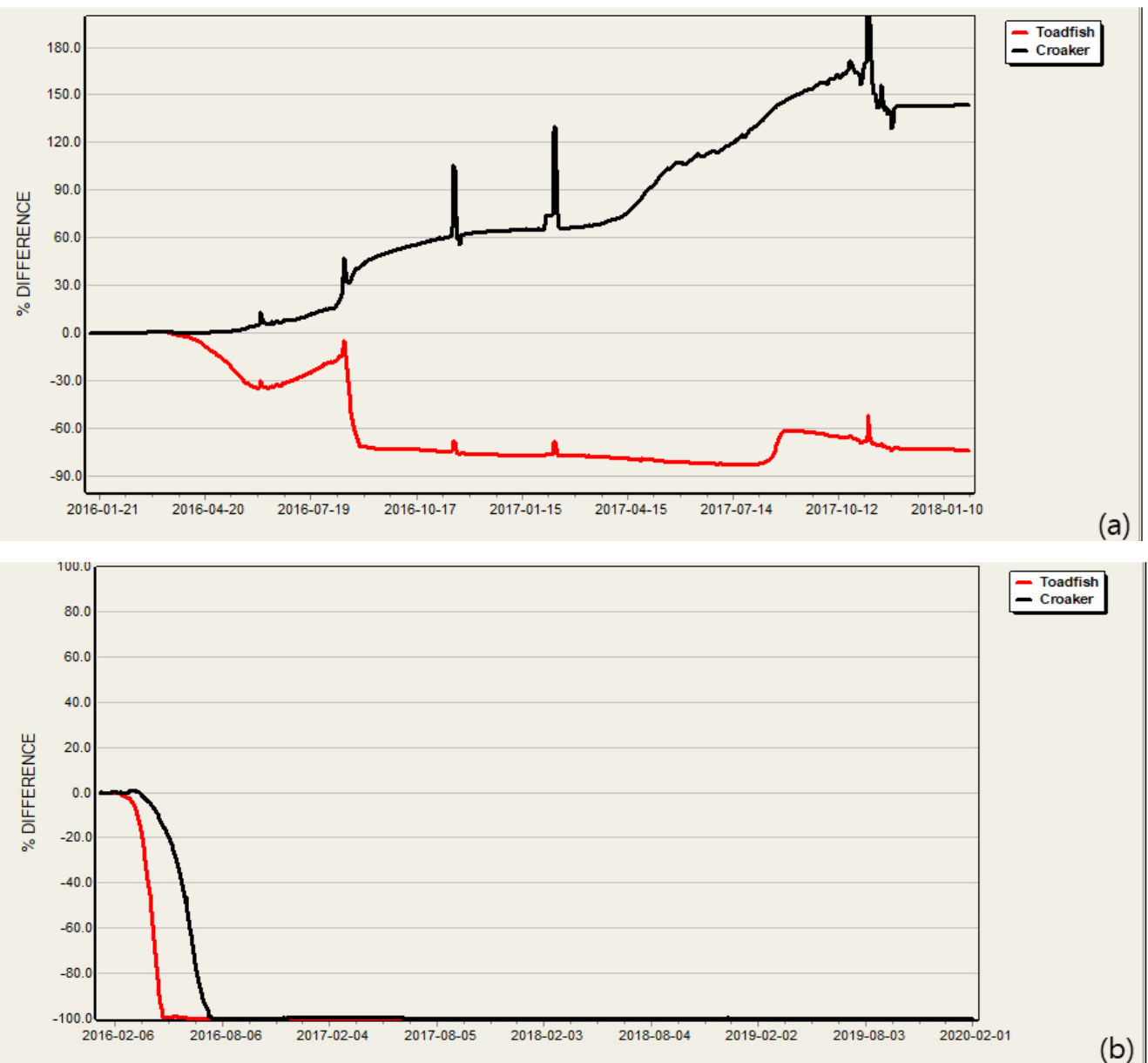

Fig. 9. Simulation results for $\%$ difference of fishes using calibrated AQUATOX model on Nakdong estuary when $0.4 \mathrm{ug} / \mathrm{L}$ of chlorpyrifos was added as (a) spike loading and (b) constant loading.

(33.4\%), 깔따구(chironomid)(13\%), 패충류(ostracod)(12.9\%), 게(7.5\%), 새우(7.5\%) 순으로 유기물 퇴적물을 주식으로 하 기 때문에 환경변화에 민감한 생물체를 주식으로 하는 Toadfish에 비해 성장하기 좋은 조건이다. Toadfish의 경우에 는 깔다구(12.7\%), 패충류(12.7\%), 달팽이(12.7\%), 복족류 (gastropod)(12.7\%), 게(12.7\%), 새우(12.8\%)를 주식으로 하고 있다. Fig.8(a)를 통해 일시 유입의 경우에는 요각류와 게가 여름철에 성장하는 것을 알 수 있고 다른 무척추동물의 경우에 는 대부분의 기간동안 감소하는 것을 알 수 있었다. 따라서, Toadfish는 Croaker보다 성장 조건이 좋지 않아 Croaker가 증가 하는 반면에 Toadfish는 감소하는 것으로 판단된다. Fig.9(b) 의 지속유입의 경우에는 독성효과로 인해 Toadfish와 Croaker 모두 사멸하는 것을 확인할 수 있다.

\section{4. 결론}

낙동강 하구역 생태계를 정확히 모사하기 위해 AQUATOX 모델을 적용하여 하구역 생태계 모델을 구축하였다. 측정 데 이터(클로로필-a)를 이용하여 모델을 검량하였고 다른 측정자
료를 이용하여 모델 검증을 수행하였다. 모델 검증이 완료된 후 오염물질인 제초제 유입 상황을 가정하여 생태계가 어떻게 반응하는지를 예측하여 보았다. 본 연구를 통해 다음과 같은 결론을 얻을 수 있었다.

1) AQUATOX 모델을 이용하여 낙동강 하구역 생태계를 표현할 수 있는 모델을 구축하였고 기존 측정자료를 이용하여 검량과 검증을 수행하였다. 검량은 클로로필-a를 이용하였고 검증은 $\mathrm{TN}, \mathrm{TP}, \mathrm{DO}$ 측정자료를 이용하였다.

2) 하구역 생태계의 식물성 플랑크톤은 은편모조류, 녹조류, 돌말류, 남조류로 구성되어 있으며 이 중 은편모조류가 우점 종으로 확인되었다. 녹조류, 돌말류, 그리고 남조류는 하굿둑 방류 시 방류수에 포함된 낙동강 본류 플랑크톤의 유입인 것 으로 판단된다. 동물성 플랑크톤의 우점종은 요각류였으나, 동물성 플랑크톤은 방류수의 유입 시 대부분 해양으로 유출되 는 것으로 확인되었다.

3) 갑각류의 경우 게와 새우가 우점종으로 모델 예측값과 기존 측정값이 일치하여 모델의 정확성을 정성적으로 확인할 수 있었다.

4) 어류의 경우 하구역 내부에서 측정된 자료가 없으므로 
연구지역과 가장 근접한 지역의 측정자료를 사용하였다. 기존 자료의 경우 달고기와 황아귀가 우점종으로 되어 있었고 모델 결과도 이와 유사한 것으로 파악되었다.

5) 검증된 모델을 이용하여 제초제가 $0.4 \mathrm{ug} / \mathrm{L}$ 의 농도로 일 시적 혹은 지속적으로 유입이 된 경우에 생태계에 미치는 영 향을 예측하였다. 지속적 유입의 경우 어류의 소멸 및 타 생태 계 구성요소의 감소를 가져왔으며, 일시적 유입의 경우에는 초기 유입 시 생태계에 영향을 주었으나 이후 생태계 회복 조짐을 보여주었다.

6) 낙동강은 부산시민의 소중한 식수원이지만 다양한 형태 의 오염원으로부터 위협을 받고 있는 상태이다. 따라서, 발생 가능한 환경오염을 예측하고 이를 해결할 수 있는 방안을 찾는 것이 매우 시급한 과제라고 할 수 있다. 이에 본 연구에 서는 생태계 예측 모델인 AQUATOX를 이용하여 낙동강 하 구역을 모사하는 하구역 생태계 모델을 구축하였으며 이를 이용하여 낙동강 하구역의 환경보전에 기여할 수가 있다고 판단한다.

\section{Acknowledgement}

본 연구는 한국연구재단의 연구비 지원으로 수행되었습니 다(과제번호: C-D-2018-0411). 이에 감사드립니다.

\section{References}

1. S. Park, J. Lee, J. Choi, N. Heo, S. An, Study on the long-term changes in water quality and benthic ecology and evaluation on effect of the barrage in Nakdong River Estuary, J. Wet. Res., 18(1), 58-67(2016).

2. K. Jeong, D. Kim, G. Joo, Delayed influence of dam storage and discharge on the determination of seasonal proliferations of Micrycystis aeruginosa and Stephanodiscus hantzschii in a regulated river system of the lower Nakdong River (South Korea), Water Res., 41(6), 1269-1279(2007).

3. J. Song, B. Yoon, J. Kim, C. Lim, S. Woo, Spatial and temporal variability of residual current and salinity distribution according to freshwater discharge during monsoon in Nakdong River Estuary, J. Korean Soc. Coast. Ocean Eng., 26(3), 184-195(2014).

4. S. Park, H. Yoon, I. Lee, H. Kim, Correlation between meterological factors and water discharge from the Nakdong River Barrage, Korea, J. Korean Soc. Mar. Environ. Saf,, 14(2), 111-117(2008).

5. I. Kwak, A study of characterics about water quality variation between the weir in the Nakdonggang basin, Materer's Thesis, Kyungpook National University, Daegu, Korea(2014).

6. S. Hong, J. Khim, J. Park, M. Kim, W. Kim, J. Jung, S. Hyun, J. Kim, H. Lee, H. J. Choi, G. Codling, J. P. Giesy,
In situ fate and partitioning of waterborne perfluoroalkyl acids (PFAAs) in the Youngsan and Nakdong River estuaries of South Korea, Sci. Total Environ., 445-456, 136-145(2013).

7. S. We, C. Yoon, B. Min, Horizontal distributions and their exotoxicological implications relations to PCBs, DDTs, $\mathrm{HCHs}$, and $\mathrm{HCB}$ in sediments in the West Nakdong River, J. Life Sci., 22(3), 332-339(2012).

8. N. Liu, X. Li, D. Zhang, Q. Liu, L. Xiang, K. Liu, D. Yan, Y. Li, Distribution, sources, and ecological risk assessment of polycyclic aromatic hydrocarbons in surface sediments from the Nantang Coast, China, Mar. Pollut. Bull., 114(1), 571-576(2017).

9. S. Shin, K. Baek, M. Song, The evaluation for maximum Chl-a site observed in the mid to lower Nakdong river, Korean J. Ecology and Environment, 35(1), 21-27(2002).

10. H. Park, C. Park, M. Song, K. Baek, S. Shin, Evaluation of water quality characteristic using factor analysis in the Nakdong River, J. Korean Soc. Water Environ., 17(6), 693-701(2001).

11. Y. Lee, K. An, Actual vegetation and vegetation structure at the coastal sand bars in the Nakdong estuary, South Korea, Korean J. Environ. Ecol., 26(6), 911-922(2012).

12. L. Zhang, J. Liu, Y. Li, Y. Zhao, Applying AQUATOX in determining the ecological risk assessment of polychlorinated biphenyl contamination in Baiwangdian Lake, North China, Ecol. Modell., 265, 239-249(2013).

13. L. Zhang, J. Liu, AQUATOX coupled foodwed model for ecosystem risk assessment of Polybrominated diphenyl ethers (PBDEs) in lake ecosystems, Environ. Pollut., 191, 80-92(2014).

14. A. Lombardo, A. Franco, A. Pivato, A. Barausse, Food web modeling of a river ecosystem for risk assessment of down-the-drain chemicals: a case study with AQUATOX, Sci. Total Environ., 508, 214-227(2015).

15. M. Rode, U. Suhr, G. Wriedt, Multi-objective calibration of a river water quality model-information content of calibration data, Ecol. Modell., 204(1-2), 129-142(2007).

16. Y. Ye, K. Bak, D. Oh, C. Lee, Y. Lee, H. Jung, Ecological monitoring for Nakdong estuary, Annual Report, 101-146 (2019).

17. J. Beukema, Biomass and species richness of the macrobenthic animals living on tidal flats of the Dutch Wadden sea, Neth. J. Sea Res., 10(2), 236-261(1976).

18. J. Lee, C. Yang, T. Lee, Distribution and pollution assessment of heavy metals in surface sediments near Gwangan Bridge, J. Korean Geo-Environ. Soc., 19(11), 15-22(2018).

19. Z. Gu, M. Wu, K. Li, P. Ning, Variation of heavy metal speciation during the pyrolysis of sediment collected from Dianchi Lake, China, Arabian J. Chem., 10(2), S2196-S2204 (2017).

20. S. Park, J. Lee, J. Choi, N. Heo, S. An, Study on the long-term changes in water quality and benthic ecology and evaluation on effect of the barrage in Nakdong River Estuary, J. Wet. Res., 18(1), 58-67(2016). 
21. M. Yoo, S. Youn, K. Park, A. Kim, S. Yoon, Y. Suh, The characteristics of spatio-temporal distribution on phytoplankton in the Nakdong River Estuary, during 2013-2015, J. Korean Soc. Mar. Environ. Saf., 22(6), 738-749(2016).

22. J. Kang, M. Kim, Distributional characteristics of mesozooplankton community in Nakdong river estuary, J. Korean Academia-Ind. Co. Soc., 21(7), 1-11(2020).

23. J. Lee, J. Lee, J. Kim, D. Lee, Y. Shin, D. Jang, Seasonal species composition of marine organism collected by a shrimp beam trawl in Nakdong River Estuary, Korean J. Icht., 21(3), 177-190(2009).

24. H. Jeong, U. Kim, T. Im, Y. Lim, J. Oh, Occurrence, seasonal variation and distribution characteristics of semi-volatile organic pollutants comprising phenols and pesticides from Nakdong River Basin and wastewater effluents, Korea, J. Environ. Anal. Health Toxicol., 16(4), 229-238(2013).

25. J. Yoo, D. Yang, K. Kim, K. Lee, Distribution of organophosphorus pesticides in Asan and Kyeonggi Bay, Korea, J. Korean Soc. Mar. Environ. Energy, 5(1), 38-50(2002).

\section{Declaration of Competing Interest}

The authors declare that they have no known competing financial interests or personal relationships that could have appeared to influence the work reported in this paper.

\section{Authors and Contribution Statement}

\section{Thilananh Hoang}

Department of Environmental Engineering, Pukyong National University, Graduate Student, ORCID (1) 0000-0003-1857-2704: Validation, Writing.

\section{Duytrinh Nguyen}

Department of Environmental Engineering, Pukyong National University, Postdoctoral Researcher, ORCID (C) 0000-0002-72411488: Validation, Writing.

\section{Junhyup Lee}

Department of Environmental Engineering, Pukyong National University, Assistant Professor, ORCiD(C) 0000-0002-2179-0035: Methodology.

\section{Kyungsoo Han}

Department of Spatial Information Engineering, Pukyong National University, Professor, ORCID () 0000-0002-5031-0256: Methodology.

\section{Taeyoon Lee}

Department of Environmental Engineering, Pukyong National University, Professor, ORCID (1) 0000-0002-7456-8227: Conceptualization, Methodology. 